\title{
Exploring the financial rationales of Dutch forest holdings and their relation with financial results
}

\author{
Marjanke A. Hoogstra-Klein ${ }^{1}$ (B)
}

Received: 7 February 2016/Revised: 15 August 2016/Accepted: 23 August 2016/Published online: 7 September 2016

(C) The Author(s) 2016. This article is published with open access at Springerlink.com

\begin{abstract}
The financial situation of many forest holdings in the Netherlands is a major concern. For example, the yearly overview of Dutch private forest holdings larger than 5 ha shows that over the last 30 years, the average annual results were negative during most years. However, it should be taken into account that not all forest holdings focus primarily on the generation of financial benefits. Surprisingly, no studies relating financial rationales and financial results have yet been conducted. The aim of the present study was, therefore, to provide a better understanding of the financial situation of forest holdings, using Dutch forest holdings as a case study, by (1) determining their financial rationales and (2) relating these financial rationales to their financial results. A survey was conducted, in which the owners and managers of 205 forest holdings in the Netherlands participated. Based on a cluster analysis, these holdings could be classified into five rationales: 'hobby owners'; 'efficiencybased owners'; 'budget producers'; 'break even players'; and 'economically oriented owners'. Different financial rationales led to differences in financial results: owner types that were more strongly oriented towards financial benefits generally produce better results on average. However, the findings also showed that not all forest owners financially orientated on benefits achieved positive results. The findings give a better understanding of forest holdings and the financial results of their holdings, and provide a basis for further research and policy development.
\end{abstract}

Communicated by Martin Moog.

Marjanke A. Hoogstra-Klein

Marjanke.Hoogstra@wur.nl

1 Forest and Nature Conservation Policy group, Wageningen University, P.O. Box 47, 6700 AA Wageningen, The Netherlands
Keywords Business management $\cdot$ Clustering $\cdot$ Forest owner objectives - Forest owner typology - The Netherlands

\section{Introduction}

The financial situation of many forest holdings in the Netherlands is a major concern. For example, the yearly overview of Dutch private forest holdings larger than 5 ha shows that over the last two decades the annual revenues were not high enough to cover the cost of forest operations in most years (Silvis and Voskuilen 2013) (see Fig. 1).

Favourable results in some recent years (mainly due to the relatively high timber prices in those years) might give the impression that the situation is improving. However, these numbers firstly hide the fact that there are major differences between individual holdings. For example, in 2011, $30 \%$ of the Dutch private forest holdings in the overview delivered a negative result of more than 100 Euros per hectare (Silvis and Voskuilen 2013). Secondly, the financial results of most forest holdings rely on a certain extent of self-generated financial means (such as timber sales or hunting revenues). During recent decades, between 33 and $50 \%$ of the total revenues of Dutch private forestry holdings were accounted for by subsidies (Silvis and Voskuilen 2013). Severe budget cuts of the Dutch Government in forest and nature management in recent years-a result of general budget cuts of the Dutch Government due to ongoing financial crisis-threaten to worsen the financial situation of many of the private forest holdings in the years ahead.

What these average numbers, however, also hide, is the fact that forest owners might have very different motivations and objectives that influence financial results. 


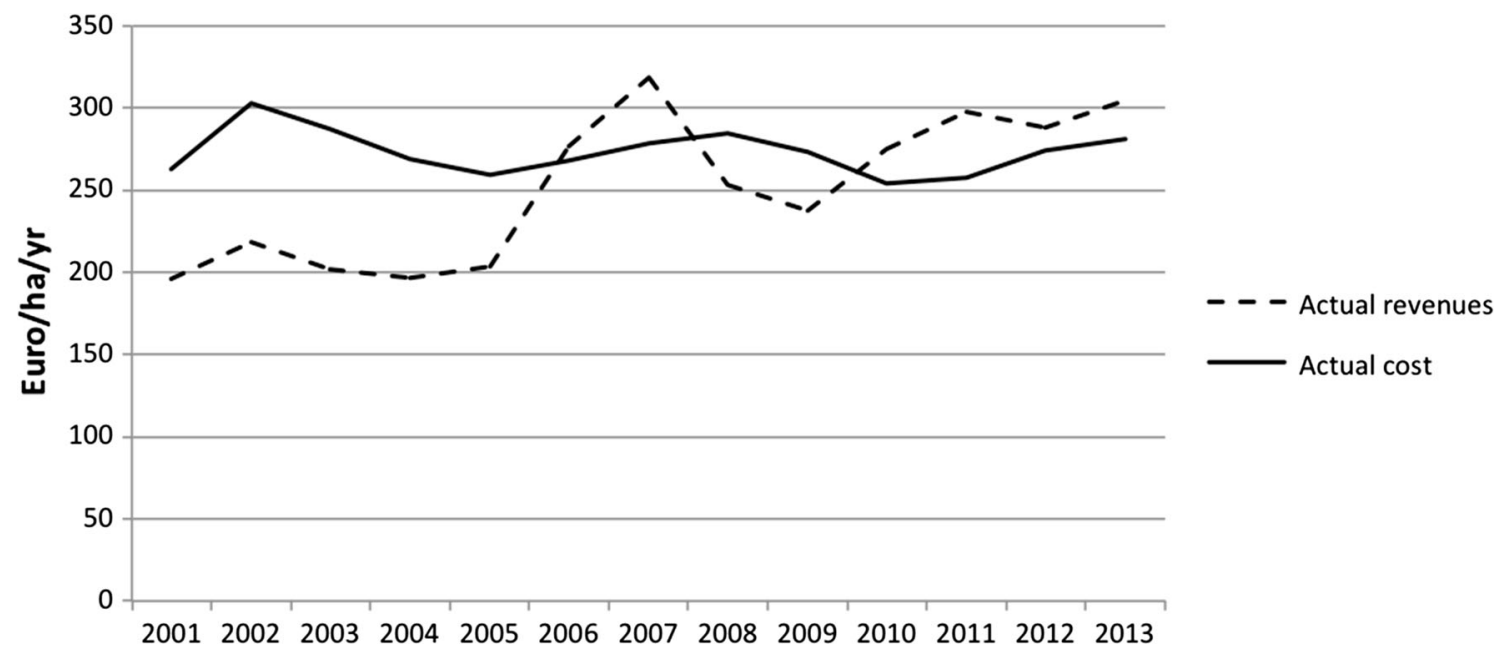

Fig. 1 Financial results of private forest holdings larger than 5 ha in the Netherlands (based on: Silvis and Voskuilen 2013)

Whereas some owners explicitly focus on the issue of production and the generation of income, other forest owners focus their attention on other aspects of forest ownership to realise other, non-financial targets in the forests that they manage. Research amongst small forest owners in the Netherlands, for example, has shown that many of these owners mainly regard their forest as a hobby (Hoogstra and Flier 2004; Wiersum et al. 2005). Profit generation is not an issue for these owners; on the contrary, they are often willing to spend a part of their income on the forests, as their forest—like any other hobby—costs them money.

In other words, Dutch forest owners form a heterogeneous group, as regards the way, in which they financially manage their properties that might influence the financial results of their holding. As no distinction is drawn between the different financial motivations of forest owners in the yearly financial overviews, it cannot be concluded that forest management in the Netherlands has no, or a limited, financial perspective. Only when the financial results are related to the way, in which the forest owner calculates these results, can one draw conclusions about the financial situation of Dutch forest holdings. The problem lies with those holdings, at which financial results are negative despite a financial orientation. In the other cases, either the results are positive, or a negative result is acceptable.

Surprisingly, no studies relating to financial orientation and financial results of forest holdings have yet been conducted in the Netherlands. An exploration of the literature on international forestry has also revealed that this specific question does not appear to have been addressed before. The exploration found that studies on forest owner motivations and objectives are abundant, but are often linked to other aspects, such as risk perception (e.g.
Eriksson 2014), management strategy (e.g. Eggers et al. 2014) and decision-making styles (e.g. Hujala et al. 2013). Dhubháin et al. (2007), in their review of the literature on forest owner typologies based on owners' objectives, also concluded that no studies related owners' objectives and entrepreneurial activity in forests were available. The aim of this study is, therefore, to provide a better understanding of the financial situation of forest holdings and, therefore, allow improved discussion on this, using Dutch forest holdings as a case study, by determining:

(a) Which financial rationales motivate the different forest holdings; and

(b) How these rationales relate to the financial results of these holdings.

Towards this, a typology of forest holdings based on the way the owners of these holdings calculate, was first established. Typologies are very popular in sciences, including forestry sciences, in which a range of forest owner typologies have been developed over the last decades. A reason for their popularity is that typologies appear to provide: 'a parsimonious framework for describing complex organisational forms and for explaining outcomes such as organisational effectiveness or group thinking' (Doty and Glick 1994, p. 230). Wolf (1926, in: Punj and Stewart 1983) even indicated that a classification of objects is both the first and the last method employed by science. Therefore, in the following section, the rationale for identifying different financial motivations is presented, based on a literature review of forest owner typologies. Next, the research methodology and the results are explained. The final section presents the study's main conclusions and its limitations, and discusses the implications of this study's results. 


\section{Types of forest owners}

During the last decades, a vast range of forest owner typologies have been constructed. All these typologies differ according to the purpose of the research carried out (Dhubháin et al. 2007; Hujala et al. 2013) and the interests of the authors and/or the contextual audiences (Hujala et al. 2013). The typologies are, for example, based on the value orientations of forest owners (Karppinen 1998), or-as is the case in most of the studies-on ownership motivations and objectives (Boon et al. 2004; Kendra and Hull 2005; Ross-Davis and Broussard 2007). In some cases, the typology is constructed around specific groups of forest owners, such as new forest owners (Hogl et al. 2005; Karppinen 2012), family forest owners (Ross-Davis and Broussard 2007; Hujala et al. 2013), small-scale private woodland owners (Urquhart and Courtney 2011) or nonindustrial private forest owners (Karppinen 1998; Jennings and van Putten 2006). Most of the typologies have been developed on country level, some have a regional focus (e.g. Richter 2005; Nichiforel 2010), and there are rare typologies with an international focus (such as the research of Wiersum et al. (2005) of forest owners in Austria, Denmark, Germany, Greece, Hungary, Ireland, the Netherlands and Spain). Typologies have been set up for different purposes, including: customer segmentation (Hujala et al. 2013); better communication between authorities and owners (Boon et al. 2004); to understand entrepreneurship amongst forest owners (Dhubháin et al. 2007); and to develop owner-specific policies (Van Herzele and Van Gossum 2008).

None of these typologies, however, explicitly focus on financial rationales and/or financial results. An exception, as established by Schanz (2000), of Dutch forest owners forms the typology for this study. Schanz (2000) suggested that in the Netherlands, five main categories of forest management motivations can be distinguished that are directly related to the way forest owners calculate. These categories are (Schanz 2000) $)^{1}$ :

1. Management purely for pleasure, as a hobby, with a budget for the hobby available (as with other hobbies, such as reading books, gardening, participating in sports). ('Hobby forest owners').

2. Management with the intention to realise certain effects or certain achievements, either because others want this or because the responsible person sees this as important - a certain budget is needed to realise the effects or achievements. ('Budget-based forest owners').

\footnotetext{
${ }^{1}$ Names/labels of the different categories of owners assigned by the author of this article.
}

3. Management to 'break even'-this means no profit is made, but the costs are covered by revenues. ('Break even forest owners').

4. Management to generate (part of) income (forests as a source of livelihood) - a yearly profit is required for an income. ('Income forest owners').

5. Management as an investment option-a return on investment needed, i.e. profit is required over a period of time. ('Investment forest owners').

However, this typology is the result of a theoreticalanalytical exploration and has not yet been tested for its validity and reliability. The forest owner typologies developed, so far, on the contrary, are mostly developed inductively (Boon et al. 2004; Ingemarson et al. 2006) and are groupings based on empirical data (Ingemarson et al. 2006).

Analytical comparisons of these forest owner typologies have, however, identified analogies in owner classifications, which seem to confirm the categories distinguished by Schanz (2000). Hobby forest owners, for example, are distinguished in several studies. Boon et al. (2004) classified Danish private forest owners into three categories: (1) classic forest owners, who valued their forest for economic considerations; (2) hobby forest owners, who valued their forest for the lifestyle and recreational opportunities it provides; and (3) indifferent forest owners, who did not value their forests. The hobby owner, who 'is motivated not so much by financial concerns' (Boon et al. 2004, p. 54), is the second-largest owner group in their research (about $30 \%$ of the sample of 1220 respondents). Karppinen and Tiainen (2010, in Karppinen 2012) studied future forest owners and found that one of the five types can be labelled as a hobby owner. In studying forest owners in different European countries, Wiersum et al. (2005) classified $62 \%$ as hobby owners.

The categories 'income' (livelihood) and 'investment' motivation are also recognised in forest owner typologies. Mizaraite and Mizaras (2005), for example, talk about 'business men'; a group of forest owners who focus on earning an income by selling (non-wood) products.

Karppinen $(1998,2000)$ described a group of owners, who are self-employed and who focus on regular sales as a source of income, as well as employment. He also identified forest owners that consider their forest to be an investment and a security for the future. Different typologies also show a combination of the two motivations in one category. Von Mutz et al. (2002) distinguished a group of 'economically oriented owners', encompassing forest owners, who value their forest as a source for both income and long-term economic security. Jennings and van Putten (2006) also found one group of owners, whom they called: 'income and investment owners' and who essentially share 
the same characteristics as the "economically oriented owners' of Von Mutz et al. (2002). Stanislovaitis et al. (2015) talk about 'forest businessmen', who regard their forests as an investment, with efficient profit generation as a main goal.

The two other groups of Schanz (budget-based and break even forest owners) are more difficult to find in the forest owner typologies, per se. However, several studies refer to these types of owners. Sutherland et al. (2011), for example, reported that many landowners in Scotland seek to 'break even'. Although also not empirically based, Bettinger et al. (2010) have defined different economic challenges for forest management, amongst which 'the need to break even' and 'the need to operate within a budget' are included.

In conclusion, the different studies provide evidence that supports the existence of different types of owners based on the way they calculate financial results and, therefore, form the starting point for determining the financial rationale of this study.

\section{Materials and methods}

\section{Research approach}

The empirical data used in this paper were collected in the frame of a research project that focuses on entrepreneurship and innovation in Dutch forest and nature management. This research project was part of the research theme of the Innovation Network of the Dutch Ministry of Economic Affairs entitled: 'Nature and landscape: Towards new forms of participation and financing'. For this research project, a nationwide survey on entrepreneurship and innovation was conducted amongst Dutch public and private forest owners and forest management organisations.

\section{Population, sample and (non-)response}

The parent population, i.e. the target group of the research project, consisted of the owners/managers of all Dutch forest holdings (both public and private) with forest properties over 5 ha (a total number of 2008 forest holdings). This population originated from the property register of the Dutch Industrial Board for Forest and Nature, to which all Dutch forest properties over 5 ha must be registered, and Dutch forest properties under 5 ha can be registered voluntarily.

The first invitation to participate in a Web survey was sent around via the newsletter of the Dutch Industrial Board for Forest and Nature. The response was very low: 44 forest owners responded, of which only 18 filled the survey completely. A second invitation was, therefore, sent either via direct e-mail (with a direct link to the Web survey) when an e-mail address for the individual was known, or via a printed survey with a cover letter and a postage-paid envelope for return mail. In total, 187 people responded to the second invitation (83 through the Web survey and 103 via paper). This means that a total of 205 surveys were completed: a response rate of $10.2 \%$. An overview of the characteristics of the respondents is given in Table 1.

The low response rate may have been due to the relatively long survey, although several studies (e.g. Kanuk and Berenson 1975; Jobber 1989) have not found any evidence for a relation between response rate and survey length. Another reason might have been a negative attitude towards the survey (Ingemarson et al. 2006). Several factors may come into play in this respect, such as the survey content and 'survey fatigue'. The content of the survey is considered to be one of the most important inducement factors in participation (Greer et al. 2000), and the topic might have not been appealing enough to the Dutch forest owners. Survey fatigue may also have suppressed the response rate (Porter et al. 2004), as in recent years, Dutch forest owners have been frequently presented with different surveys covering a range of topics. The low response rate in the first round, and the fact that in the second round most of the surveys were answered via paper, also hints at the fact that the Web survey, considered beforehand to have been the most efficient way for respondents to react, might not have been the best data capture technique for this specific population.

The low response rate may be a cause for a non-response bias. Two methods were used to investigate this bias. The first was a comparison of early and late responses, i.e. the responses of the first round and the responses of the second round, for variables related to owners' and ownership characteristics. Pearson's Chi-square test was used to evaluate possible differences between the two groups, with the assumption that the $p$ value must be less than 0.05 to show a significant difference between the early and late responses. The results presented in Table 2 indicate that none of the Chi-square tests were significant.

The second method was to compare the respondents with the total population. The variable chosen to compare was ownership type as data are available for this variable for the whole population. In the Netherlands, approximately $55 \%$ of forest areas larger than 5 ha are public property, and the others are privately owned (CBS et al. 2014). Respondents represent about 24,255 ha of public ownership (57\%) versus around 18,370 ha of private ownership (43\%), which is almost similar to the total population. This outcome in combination with the comparison of early and late responses leads to the conclusion that, despite the low sample size, there is no indication for a non-response bias. 
Table 1 Characteristics of the sample of respondents $(N=205)$

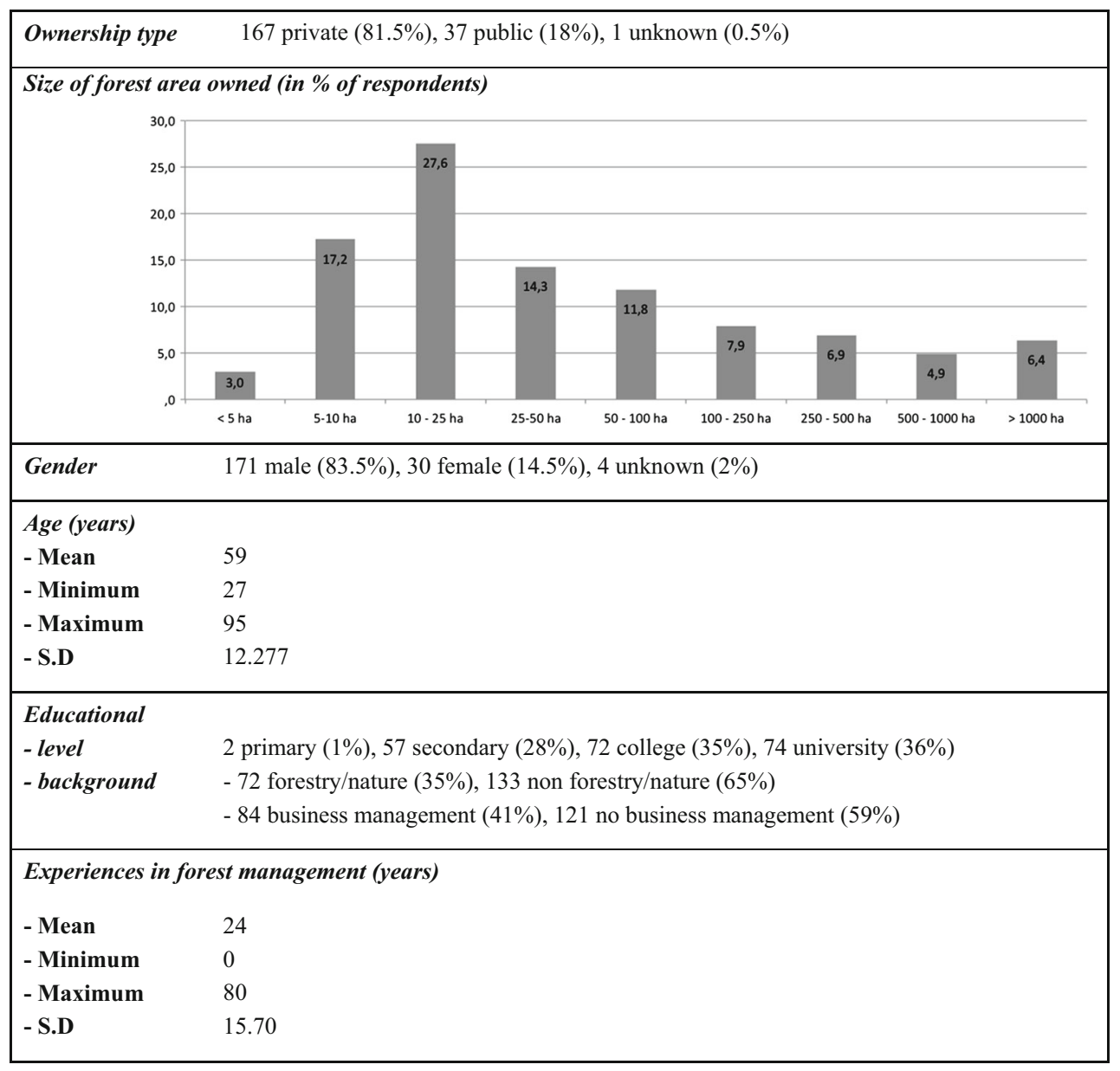

Table 2 Non-response bias analyses

\begin{tabular}{lrl}
\hline Variable tested & \multicolumn{2}{c}{ Pearson's Chi-square test } \\
\cline { 2 - 3 } & \multicolumn{1}{c}{$X^{2}$} & $p$ value (two-tailed) \\
\hline Ownership type (public/private) & 0.642 & 0.432 \\
Size of forest holding & 13.478 & 0.142 \\
Age & 5.576 & 0.134 \\
Gender & 0.047 & 0.828 \\
Educational level & 5.176 & 0.739 \\
Educational background & 1.745 & 0.418 \\
Experience & 5.292 & 0.259 \\
\hline
\end{tabular}

\section{Questionnaire}

The Web survey and the paper questionnaire were identical and included 34 questions (in Dutch) concerning:

1. The forest holding (ownership type, size and type of forest).

2. Financial aspects (motivations, yearly financial results, costs and revenues, future prospects).
3. Entrepreneurship and innovation (number of product innovations, types of products marketed, planned innovations, experience with innovations).

4. Forest owners'/managers' background (gender, age, educational level and background, years of experience).

The third section on innovation and entrepreneurship is not discussed in this article.

The five statements in Table 3 (part of the second section of the survey) formed the basis to determine the typology. These five statements are based on the ideal typology, as established by Schanz (2000). All statements emphasise different aspects of this ideal typology. The respondents were asked to assess the importance of the five statements for their own forest holding on an ordinal threepoint Likert scale, in which 1 corresponded to 'absolutely not applicable', 2 to '(somewhat) applicable' and 3 to 'very applicable'. Most frequently, Likert scales consist of five items, or in some cases, seven items. The reason for choosing a three-point Likert scale in this research was firstly, because five- and seven-point scales take longer to 
Table 3 Statements used as the basis of the typology

The forest is a hobby-as people like to read a book or participate in certain sports

Main focus is the production of certain goods and services, for which money (a certain budget), is required

The owner (needs to) earn (part of) his/her income from her forest

The forest should generate enough revenues to maintain the property/cover the cost of management

The forest is an investment object-it should generate a profit in the long term

complete (Dolnicar et al. 2011). The survey contained a lot of questions, and survey completion time can be an important factor in non-response, abandonment of surveys and a decrease in quality of answers at the end of the survey (Cape 2010). Moreover, several authors have concluded that a three-point Likert scale is often 'good enough' (Jacoby and Matell 1971). Peabody (1962) also concluded decades ago that Likert items primarily capture direction (i.e. either positive or negative) and not so much intensity (level of agreement). A three-point Likert scale, therefore, represents a viable measurement for this research.

\section{Statistical methods}

The data collected were analysed with the SPSS statistical software package, using a three-step approach:

1. Development of a typology of forest holdings using cluster analysis.

2. Analysis of significant differences of characteristics between clusters, using the Pearson's Chi-square test.

3. Analysis of significant relations between types of forest holdings and financial results, using the Pearson's Chi-square test.

To determine the different types of forest holdings, a cluster analysis was first carried out. A cluster analysis is a statistical analysis that explores the data collected and tries to identify homogenous groups of cases within the data. Although there are no strict rules for a minimum sample size to carry out a cluster analysis, Formann (1984) indicates that preferably this should be $5^{*} 2^{k}$, with $k$ the number of variables (five, in this research). The 205 respondents in this research is, therefore, sufficient (as it is well above the 160) to carry out the cluster analysis.

SPSS offers different cluster approaches, each following their own way of clustering data. This research made use of the hierarchical clustering approach. Hierarchical clustering is a widely used approach in forest owner typologies (see, for example, Boon et al. 2004; Ingemarson et al. 2006; Majumdar et al. 2008), as it is exploratory in nature, and has the advantage that no a priori assumptions must be made about the number of clusters to be found in the data
(Majumdar et al. 2008). Within the hierarchical clustering approach, different procedures exist, of which Ward's method was selected as criterion to carry out this clustering. Ward's method is an agglomerative clustering algorithm. Agglomerative means that it starts with all individual cases (in this research the respondents) as individual clusters, whilst pairs of clusters are formed in every step of the process until all cases form part of one cluster. Ward's method (also called Ward's minimum variance method) bases the selection of the pairs of clusters to be merged in each step on the minimum increase in the total within-cluster variance after merging. This increase is a weighted squared distance between cluster centres (Charrad et al. 2013). Ward's method has also been used by Boon et al. (2004), Hogl et al. (2005) and Ingemarson et al. (2006), amongst others, for determining forest owner typologies. Based on the dendrogram and a qualitative assessment of the cluster content, a five-cluster solution was found to be appropriate.

The second step was the analysis of differences in forest owners' characteristics between the clusters to gain more insight into the types of owners in the clusters distinguished. Characteristics that could be included in the analysis were: gender; age; educational level; educational background; years of experience; extent of ownership; and type of ownership (private or public). All forest owners' characteristics that were not already in categories were translated into classes. For the analysis, the Pearson's Chisquare test was used. The Chi-square test is one of the basic tests in the statistical analysis of categorical data and tests for possible relations between categorical data. This test was also used in the third and last step of our analysis, to determine significant relations between types of forest owners (i.e. their financial rationale) and the financial results. The conventional approach that the $p$ value must be less than 0.05 was followed.

\section{Results}

\section{Clusters distinguished}

The cluster analysis identified five types of forest owners/management organisations based on the answers of 183 respondents to the five statements. The mean response values per statement for every cluster are shown in Fig. 2. As this figure clearly shows, not all clusters can directly be linked to one statement, and accordingly classified in one of the types distinguished by Schanz (2000).

One cluster stood out and can directly be linked to the hobby owner of Schanz (2000). This cluster delivered a high score on the hobby statement, with low scores on all the others. The cluster was, therefore, labelled accordingly. 


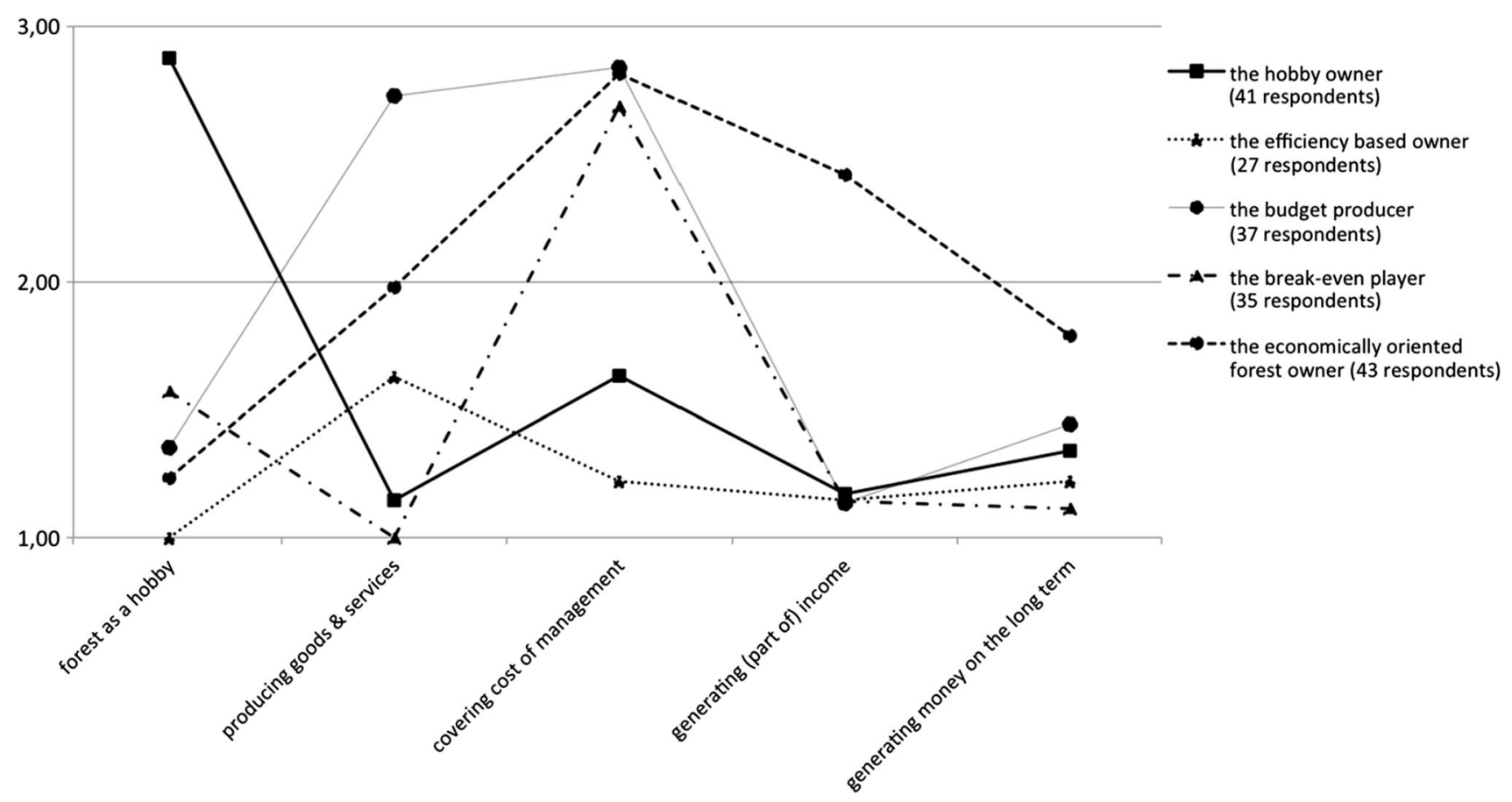

Fig. 2 Mean response values on the applicability of the different statements for the different forest properties (with $1=$ absolutely not applicable to $3=$ very applicable)

Several clusters scored highly on the covering cost statement, but only one cluster scored highly on this statement only. As this cluster reflects the ideal type of the break even owner of Schanz (2000) the most, it received the same label. The three remaining clusters showed a heterogeneous distribution of scores, combining different financial motivations. One cluster combined high scores on the production of goods and services with the covering cost statement. This cluster received, therefore, the label 'budget producer'. The cluster that combined the covering cost statement with a high score on income generation was labelled 'economically oriented forest owner'. This cluster also included the highest score of all clusters on the investment statement and, therefore, reflects the 'economically oriented forest owner', as distinguished by Von Mutz et al. (2002), best. The last, and most difficult, cluster to define was the one with low scores on all five statements. This group could not be related to one of the Schanz' motivations or to owner types distinguished in other studies. An exploration of the (open) answers of the respondents in this cluster revealed that this is a group of owners was motivated by using a certain budget as efficiently as possiblehence the name 'efficiency-based owners'.

Figure 3 summarises the comparison of the typology developed in this research, with the ideal typology, as established by Schanz (2000).
Fig. 3 Comparison of the type of owners distinguished by Schanz (2000) and this research

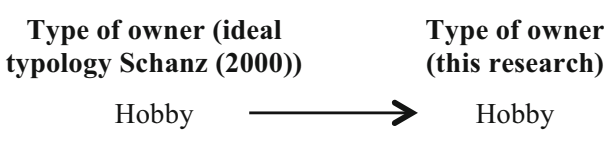

Efficiency based

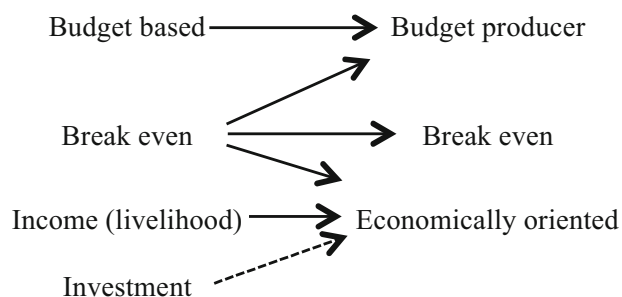

Financial rationale

Available budget for hobby, no profit needed

Budget needed for management, efficient use of money central, no profit needed, no production objectives

Budget needed to produce certain goods and services, cost of management need to be covered, no profit needed

Generation of revenues to cover the cost, no profit needed

Profit over the short and/or long term needed, minimum is to cover the cost 


\section{Characteristics of the clusters}

An overview of the results of the analysis of significant differences in owners' characteristics between the different clusters is given in Table 4. It shows that several significant differences exist, indicating a clear relationship between forest owners' characteristics and the financial rationale underlying forest holdings.

The cluster termed 'the hobby owner' (41 respondents) relates to the forest owner, who values the forest as a place for hobby activities much more than all the other groups (as can be clearly seen in Fig. 3). Producing certain goods and services is of almost no importance. The same applies to the financial aspect; there is no need to generate any profit and the forest is not perceived as a source of income or a possibility to at least cover the cost of the management. The cluster exists mainly out of private forest owners with relatively small forest areas-80\% of the properties is smaller than 25 ha. In addition, the respondents from this group tended to be older and male, and have weaker educational ties to forestry than the other types.

The cluster 'the efficiency-based owners' describes forest owners, who, like the hobby owners, attach no importance to the production of certain goods and services or to the generation of money. Unlike the hobby owners, however, these owners do not consider the forest as a hobby at all. Unlike the hobby group, this group comprised of a mix of private and public forest owners, and had the highest share of public owners of all types. Examples include: municipalities, energy companies and holiday parks, who have a certain budget for the management of their forest. Property sizes varied from 5 ha to more than 1000 ha.

Another cluster is the group of 'budget producers'. Owners in this group had more of a focus than other groups

Table 4 Values and significance of characteristics of the clusters

\begin{tabular}{|c|c|c|c|c|c|c|}
\hline Characteristic & $\begin{array}{l}\text { Hobby } \\
(N=41)(\%)\end{array}$ & $\begin{array}{l}\text { Budget based } \\
(N=27)(\%)\end{array}$ & $\begin{array}{l}\text { Budget producer } \\
(N=37)(\%)\end{array}$ & $\begin{array}{l}\text { Break even } \\
(N=35)(\%)\end{array}$ & $\begin{array}{l}\text { Economically oriented } \\
(N=43)(\%)\end{array}$ & $\begin{array}{l}\text { Total } \\
(N=183) \\
(\%)\end{array}$ \\
\hline Gender, men* & 95 & 92 & 86 & 71 & 84 & 85 \\
\hline \multicolumn{7}{|l|}{ Age (years)* } \\
\hline$\leq 40$ years & 5 & 4 & 11 & 17 & 7 & 9 \\
\hline $41-50$ years & 0 & 18 & 19 & 14 & 26 & 15 \\
\hline $51-65$ years & 56 & 67 & 46 & 49 & 44 & 52 \\
\hline$>65$ years & 39 & 11 & 24 & 20 & 23 & 24 \\
\hline \multicolumn{7}{|l|}{ Educational level } \\
\hline Primary & 2 & 0 & 0 & 0 & 0 & 1 \\
\hline Secondary & 32 & 27 & 24 & 14 & 35 & 27 \\
\hline $\begin{array}{l}\text { College/ } \\
\text { university }\end{array}$ & 66 & 73 & 76 & 86 & 65 & 72 \\
\hline \multicolumn{7}{|c|}{ Educational background } \\
\hline Forestry/nature* & 15 & 35 & 43 & 34 & 46 & 35 \\
\hline Business mgt & 32 & 42 & 43 & 40 & 50 & 41 \\
\hline \multicolumn{7}{|l|}{ Experience (years) } \\
\hline$\leq 5$ years & 8 & 8 & 11 & 3 & 2 & 6 \\
\hline $6-10$ years & 12 & 20 & 22 & 37 & 14 & 21 \\
\hline $11-20$ years & 25 & 28 & 19 & 23 & 24 & 24 \\
\hline $21-30$ years & 15 & 24 & 32 & 26 & 29 & 25 \\
\hline$>30$ years & 40 & 20 & 16 & 11 & 31 & 25 \\
\hline \multicolumn{7}{|l|}{ Size of holding** } \\
\hline$<5$ ha & 5 & 0 & 3 & 0 & 5 & 3 \\
\hline $5-25$ ha & 76 & 37 & 30 & 34 & 36 & 43 \\
\hline 26-100 ha & 12 & 37 & 24 & 31 & 26 & 25 \\
\hline $101-1000$ ha & 7 & 11 & 38 & 31 & 19 & 21 \\
\hline$>1000 \mathrm{~h}$ & 0 & 15 & 5 & 3 & 14 & 7 \\
\hline $\begin{array}{l}\text { Ownership, } \\
\text { private** }\end{array}$ & 98 & 59 & 73 & 83 & 73 & 80 \\
\hline
\end{tabular}

* Significantly different at the 0.05 level; ** significantly different at the 0.005 level 
on the production of certain goods and services, for which they require a certain budget. They need to generate money, but making a profit is not a necessity; the focus is on generating enough money to cover (part of) the cost of producing the specific goods and services these owners aim for. Several owners also have other sources of income to cover a part of the cost of the management. This group shares many characteristics with the group of budget-based owners, as a mix of private and public forest owners with varying property sizes. However, the educational ties to forestry were much stronger in this group, than in the budget-based owners group.

The cluster termed 'break even player' was characterised by high scores, i.e. on generating enough money to cover the cost of management. In other words, the forest does not have to generate a profit, but the owner should earn enough money with activities from the forest to at least cover the cost of the management of the area to keep the property intact. Which activities these are, depends on what possibilities there are at that moment. This group shared many characteristics with the group of budget-based players and producers, as this group was also a mix of private and public owners with varying property sizes.

The last cluster, the 'economically oriented forest owner', emphasised the financial aspects of the property more than others. As with the break even player, the property should at least generate enough money to cover the cost of management to keep the property intact. However, the importance of forest income generation and generating money over the short and long term is of much more importance for this group, than for all other groups. These owners comprised of mostly private forest owners with varying sizes of forests. In addition, the respondents of this group were shown to have stronger educational ties to forestry, than the other types.

\section{Financial situation of different clusters}

One question remains unanswered: How does the financial rationale relate to the financial results? Table 5 shows the types of owners in relation to the financial results for 170 of the respondents (not all respondents answered the question on financial results).

A Chi-square test shows that the results between the different clusters differ significantly $\left(X^{2}=43.532\right.$, $p<0.005)$. In particular, the efficiency-based owners scored low on their financial results: $73 \%$ of the respondents delivered (most of the times or always) a negative result. A majority of the respondents with generally negative financial results (53\%) were also found in the group of hobby owners. The other three groups had better scores, with $29 \%$ of the budget producers, $21 \%$ of the break even players and $16 \%$ of the economically oriented owners delivering negative results.

Table 5 also shows that the type of owner does not explain everything, as the differences within the types of owners were rather large. A possible explanation could also be the size of the forest area of a forest holding - in general, it has been stated that smaller forest holdings have more difficulties to reach a positive result than larger holdings. Luijt and Voskuilen (2012), for example, stated that, in general, in the Netherlands, the financial results improve with larger forest holdings. And Probos (2013) describes that the relation between forest area and result as Dutch forest holdings over 200 ha can sometimes break even, whilst Dutch forest holdings smaller than 50 ha must always invest money into the company. As the differences within the clusters in size are rather large, this might also be an explanation for the differences in financial results. The Chi-square test, however, showed that there is no significant difference between size of the area and financial result $\left(X^{2}=51.659, p>0.2\right)$. Other factors that might explain the differences, such as age of the forests, quality of the timber produced, location of the area, knowledge of the forest owner, could not be tested, as they were not included in the survey.

\section{Discussion and conclusion}

The aim of this research was to provide a better understanding of the financial situation of Dutch forest holdings by connecting financial rationales to the financial results.

Table 5 Types of owners and financial results

\begin{tabular}{lllllll}
\hline & $\begin{array}{l}\text { Total } \\
(N=170)\end{array}$ & $\begin{array}{l}\text { Hobby } \\
(N=36)\end{array}$ & $\begin{array}{l}\text { Efficiency based } \\
(N=23)\end{array}$ & $\begin{array}{l}\text { Budget producer } \\
(N=35)\end{array}$ & $\begin{array}{l}\text { Break even } \\
(N=34)\end{array}$ & $\begin{array}{l}\text { Economically } \\
\text { oriented }(N=42)\end{array}$ \\
\hline $\begin{array}{l}\text { Always/most of the times a positive } \\
\text { result }\end{array}$ & 42 & $4(11 \%)$ & $0(0 \%)$ & $13(37 \%)$ & $10(29 \%)$ & $15(36 \%)$ \\
$\begin{array}{l}\text { Most of the times playing even } \\
\begin{array}{l}\text { Sometimes a positive result, } \\
\text { sometimes a negative result }\end{array}\end{array}$ & 36 & $4(11 \%)$ & $5(21 \%)$ & $6(17 \%)$ & $11(32 \%)$ & $10(24 \%)$ \\
$\begin{array}{l}\text { Most of the times/always a negative } \\
\text { result }\end{array}$ & 60 & $19(53 \%)$ & $17(73 \%)$ & $10(29 \%)$ & $7(21 \%)$ & $7(16 \%)$ \\
\hline
\end{tabular}


The findings show the presence of five different financial rationales amongst Dutch forest holdings. The financial rationales have a significant relation with the financial results of forest holdings. Most holdings with negative financial results were found in the group of efficiencybased owners. This is probably not that surprising. This owner group was also the one group that scored low on all the statements used for the cluster analysis, i.e. without a need to make any profit or to cover the cost of management. This group is somewhat of a 'black box'. The statements used did not provide a clear understanding of the financial rationale of this group, and the only insight gained from other questions in the survey was that efficiency plays an important role. Not surprisingly, the majority of the hobby owners also scored low on financial results. However, the results indicated that almost half of the hobby owners make some money with their property. Regarding the financial results, the budget producers, the break even players and the economically oriented provided the clearest results. This indicates that forest owners that need to make money (either to cover the cost of management or to gain a profit with their holding) achieve better results, in general, than those who do not need to. Considering this outcome, it makes sense to relate the financial rationales to the financial results of the holdings.

The outcomes of this study give a more nuanced view on the financial situation of the Dutch forest holdings, indicating that the sombre outlook on the financial situation of these holdings, portrayed in yearly average numbers, might be too pessimistic. Distinguishing between different groups gives a more refined image of the sector: it shows the overall financial situation and indicates, at the same time, where the real difficulties are, i.e. with the holdings that need to generate money, but do not succeed. Unfortunately, the survey did not give insight into how precarious the financial situation of these holdings is: the survey only dealt with financial results in categories (negative, break even, positive) and not with absolute numbers. This means that a negative result was represented by everything below 0 Euro. The same applies to holdings that do generate money: this research does not answer the question, as to whether the generated money is sufficient or not, e.g. whether the owner must gain a livelihood from his property or not.

It is important to note that this study is a first exploratory study and more testing should be undertaken to ascertain if that the typology is a stable typology of the way forest owners calculate financial results. Further research is also necessary on the efficiency-based forest owner, who is still largely a 'black box' regarding financial rationale. Research could also be carried out in other countries to determine to what extent the typology is exemplary for the Netherlands, or if it applies to other countries as well. The forest owner typologies established in other countries give the impression that (some of) the rationales might also apply to these countries.

In further research, one should not only focus on the different financial rationales and the financial results, but also include the activities of forest owners and forest managers. As described by Dhubháin et al. (2007), it is highly likely that forest owners with an economic concern will engage more in activities that increase the financial results. Dhubháin et al. (2007) mention not only forest management activities such as timber harvesting, but also entrepreneurial activities related to forest management. The latter is especially interesting, as the forest sector is not regarded as highly entrepreneurial (Niskanen et al. 2007); although this is considered necessary for the forest sector to be able to cope with continuously changing conditions (Rametsteiner and Weiss 2006). Further research could explore if the typology also has the potential to provide more insight into these aspects. In this respect, the analysis of Part III of the survey in relation to the outcomes of this study could offer some initial insights.

If further research is carried out, and a stable typology of financial rationales is established, the typology could be a potentially useful tool for forest policy and advice. Bliss and Martin (1989), for example, stressed the importance of the understanding of the motivations of forest owners for successful policy initiatives and for the promotion of successful sustainable management. Boon and Meilby (2007) described the importance of forest owner typologies for forest policy and advice, as these typologies make it possible to target the types distinguished differently and more effectively. The use of a typology for policy is 'one way of avoiding a blanket approach to landholders, and at the same time recognising that it is impossible to have policies and programs tailored to each individual' (Emtage et al. 2006, p. 79).

In conclusion, this research can be considered as a first step towards a better understanding of the behaviour of forest owners and the financial results of their holdings, and could provide a basis for further research and policy development.

Acknowledgments The author would like to acknowledge the financial support of the Innovation Network of the Dutch Ministry of Economic Affairs enabling this study. The author also thanks all of the forest owners and forest managers for participating in the survey, and Bosschap (the Dutch Industrial Board for Forest and Nature) for their help and support in the research. Thanks are also due to the anonymous reviewers for their constructive criticism.

Open Access This article is distributed under the terms of the Creative Commons Attribution 4.0 International License (http://crea tivecommons.org/licenses/by/4.0/), which permits unrestricted use, distribution, and reproduction in any medium, provided you give appropriate credit to the original author(s) and the source, provide a link to the Creative Commons license, and indicate if changes were made. 


\section{References}

Bettinger P, Boston K, Siry JP, Grebner DL (2010) Forest management and planning. Academic Press, New York

Bliss JC, Martin AJ (1989) Identifying small-scale forest management motivations with qualitative methods. For Sci 35:601-622

Boon TE, Meilby H (2007) Describing management attitudes to guide forest policy implementation. Small Scale Forest 6(1):79-92

Boon TE, Meilby H, Thorsen BJ (2004) An empirically based typology of private forest owners in Denmark: improving communication between authorities and owners. Scand J For Res 19(S4):45-55

Cape P (2010) Questionnaire length, fatigue effects and response quality revisited. Survey Sampling International 1-11

CBS, PBL, Wageningen UR (2014). Eigendom van bossen, 1975-2012 (indicator 1262, versie 05, 23 juli 2014). www. compendiumvoordeleefomgeving.nl. CBS, Den Haag; Planbureau voor de Leefomgeving, Den Haag/Bilthoven en Wageningen UR, Wageningen. Date of Access 27 July 2016

Charrad M, Ghazzali N, Charrad MM (2013) Package 'NbClust'. http://cedric.cnam.fr/fichiers/art_2554.pdf. Accessed 29 July 2016

Dhubháin ÁN, Cobanova R, Karppinen H, Mizaraite D, Ritter E, Slee B, Wall S (2007) The values and objectives of private forest owners and their influence on forestry behaviour: the implications for entrepreneurship. Small Scale Forest 6(4):347-357

Dolnicar S, Grun B, Leisch F, Rossiter J (2011) Three good reasons NOT to use five and seven point Likert items. In: 21st CAUTHE national conference, Adelaide, Australia, 8-11 February 2011

Doty DH, Glick WH (1994) Typologies as a unique form of theory building: toward improved understanding and modeling. Acad Manag Rev 19(2):230-251

Eggers J, Lämås T, Lind T, Öhman K (2014) Factors influencing the choice of management strategy among small-scale private forest owners in Sweden. Forests 5(7):1695-1716

Emtage N, Herbohn J, Harrison S (2006) Landholder typologies used in the development of natural resource management programs in Australia—a review. Aust J Environ Manag 13(2):79-94

Eriksson L (2014) Risk perception and responses among private forest owners in Sweden. Small Scale Forest 13(4):483-500

Formann AK (1984) Die latent-class-analyse: Einführung in die Theorie und Anwendung. Beltz, Weinheim

Greer TV, Chuchinprakarn N, Seshadri S (2000) Likelihood of participating in mail survey research-business respondents' perspectives. Ind Mark Manag 29:97-109

Hogl K, Pregernig M, Weiss G (2005) What is new about new forest owners? A typology of private forest ownership in Austria. Small Scale For Econ Manag Policy 4(3):325-342

Hoogstra MA, Flier D (2004) Kleine boseigenaren in Nederlandleefstijlen en beheer. Small forest owners in the Netherlandslifestyle and management. Vakblad Natuur Bos Landschap 1:21-24 (in Dutch)

Hujala T, Kurttila M, Karppinen H (2013) Customer segments among family forest owners: combining ownership objectives and decision-making styles. Small Scale Forest 12(3):335-351

Ingemarson F, Lindhagen A, Eriksson L (2006) A typology of smallscale private forest owners in Sweden. Scand J For Res 21(3):249-259

Jacoby J, Matell MS (1971) Three-point Likert scales are good enough. J Mark Res 8(4):495-500

Jennings SM, van Putten IE (2006) Typology of non-industrial private forest owners in Tasmania. Small-Scale For Econ Manag Policy $5(1): 37-55$
Jobber D (1989) An examination of the effects of questionnaire factors on response to an industrial mail survey. Int J Res Mark 6:129-140

Kanuk L, Berenson C (1975) Mail surveys and response rates: a literature review. J Mark Res 12(4):440-453

Karppinen H (1998) Values and objectives of non-industrial private forest owners in Finland. Silva Fenn 32:43-59

Karppinen H (2000) Forest values and the objectives of forest ownership. Finnish Forest Research Institute research papers 757. Finnish Forest Research Institute, Helsinki Research Centre, Helsinki

Karppinen H (2012) New forest owners and owners-to-be: apples and oranges? Small-Scale For 11(1):15-26

Karppinen H, Tiainen L (2010) "Semmonen niinkun metsäkansa"suurten ikäluokkien perijät tulevaisuuden metsänomistajina. ["Sort of forest people"-future forest owners: descendants of the post war baby boom generation] Metsätieteen aikakauskirja 1:19-38

Kendra A, Hull RB (2005) Motivations and behaviors of new forest owners in Virginia. For Sci 51(2):142-154

Luijt J, Voskuilen MJ (2012) Bedrijfsuitkomsten in de Nederlandse particuliere bosbouw over 2010. Operating results for private Dutch forests in 2010. LEI Wageningen UR, The Hague. LEI report 2012-053 (in Dutch)

Majumdar I, Teeter L, Butler B (2008) Characterizing family forest owners: a cluster analysis approach. For Sci 54(2):176-184

Mizaraite D, Mizaras S (2005) The formation of small-scale forestry in countries with economies in transition: observations from Lithuania. Small Scale For Econ Manag Policy 4(4):437-450

Nichiforel L (2010) Forest owners' attitudes towards the implementation of multi-functional forest management principles in the district of Suceava, Romania. Ann For Res 53(1):3

Niskanen A, Slee B, Ollonqvist P, Pettenella D, Bouriaud L, Rametsteiner E (2007) Entrepreneurship in the forest sector in Europe, vol 52. University of Joensuu, Faculty of Forestry, Joensuu

Peabody D (1962) Two components in bipolar scales: direction and extremeness. Psychol Rev 69(2):65

Porter SR, Whitcomb ME, Weitzer WH (2004) Multiple surveys of students and survey fatigue. New Dir Inst Res 2004(121):63-73

Probos (2013) Bosdigitaal. Het bosbedrijf en economie. Forest Holdings and Economics. http://www.probos.net/bosdigitaal/ html/ess_bosbedrijfeconomie.html. Date of Access 21 Jan 2013 (in Dutch)

Punj G, Stewart DW (1983) Cluster analysis in marketing research: review and suggestions for application. J Mark Res 20(2):134-148

Rametsteiner E, Weiss G (2006) Innovation and innovation policy in forestry: linking innovation process with systems models. For Policy Econ 8(7):691-703

Richter KJ (2005) Using attitudes and motivations to segment the landowner audience: a typology of family forest owners in the Missouri Ozarks and description of management and information behaviors. Doctoral dissertation, University of MissouriColumbia

Ross-Davis A, Broussard S (2007) A typology of family forest owners in north central Indiana. North J Appl For 24(4):282-289

Schanz H (2000) Hoe rekenen boseigenaren? How do forest owners calculate? Speech held for the Forest Group Gelderland, 13th of June 2000 (in Dutch)

Silvis HJ, Voskuilen MJ (2013) Bedrijfsuitkomsten in de Nederlandse particuliere bosbouw over 2011. Operating results for private Dutch forests in 2010. LEI Wageningen UR, The Hague. LEI report 2013-026 (in Dutch) 
Stanislovaitis A, Brukas V, Kavaliauskas M, Mozgeris G (2015) Forest owner is more than her goal: a qualitative typology of Lithuanian owners. Scand J For Res 30(5):478-491

Sutherland LA, Barnes A, McCrum G, Blackstock K, Toma L (2011) Towards a cross-sectoral analysis of land use decision-making in Scotland. Landsc Urb Plan 100(1):1-10

Urquhart J, Courtney P (2011) Seeing the owner behind the trees: a typology of small-scale private woodland owners in England. For Policy Econ 13(7):535-544

Van Herzele A, Van Gossum P (2008) Typology building for ownerspecific policies and communications to advance forest conversion in small pine plantations. Landsc Urb Plan 87(3):201-209
Von Mutz R, Borchers J, Becker G (2002) Forstliches engagement und forstliches engagmentpontenzial von privatwaldbsizern in nordrhein-westfalen-analyse auf der basis des mixed-raschmodels. Forstwiss Centralblatt 121:35-48

Wiersum KF, Elands BHM, Hoogstra MA (2005) Small-scale forest ownership across Europe: characteristics and future potential. Small Scale For Econ Manag Policy 4:1-19

Wolf A (1926) Essentials of scientific method. Macmillan Company, New York 